\title{
THE IMPACT OF EMPLOYEE COMMUNICATION AND PERCEIVED EXTERNAL PRESTIGE ON ORGANIZATIONAL IDENTIFICATION
}

\author{
Ale Smidts, Cees B.M. van Riel \& Ad Th.H. Pruyn
}

\begin{tabular}{|c|c|}
\hline \multicolumn{2}{|c|}{ ERIM REPORT SERIES RESEARCH IN MANAGEMENT } \\
\hline ERIM Report Series ref. number & ERS-2000-01-MKT \\
\hline Publication status / version & draft / version January 2000 \\
\hline Number of pages & 34 \\
\hline Email address first author & Asmidts@fbk.eur.nl \\
\hline ISBN number(s) & $\begin{array}{l}\text { 90-5892-001-1 (printed version) } \\
\text { 90-5892-002-X (electronic version) }\end{array}$ \\
\hline URL location (electronic version) & http://www.eur.nl/WebDOC/doc/erim/erimrs20000314094053.pdf \\
\hline Address & $\begin{array}{l}\text { Erasmus Research Institute of Management (ERIM) } \\
\text { Rotterdam School of Management / Faculteit Bedrijfskunde } \\
\text { Erasmus Universiteit Rotterdam } \\
\text { PoBox } 1738 \\
3000 \text { DR Rotterdam, The Netherlands } \\
\text { Phone: \# 31-(0) 10-408 } 1182 \\
\text { Fax: \#31-(0) 10-408 } 9020 \\
\text { Email: } \quad \text { info@erim.eur.nl } \\
\text { Internet: } \quad \text { www.erim.eur.nl }\end{array}$ \\
\hline
\end{tabular}

Bibliographic data and classifications of all the ERIM reports are also available on the ERIM website: www.erim.eur.nl 


\title{
THE IMPACT OF EMPLOYEE COMMUNICATION AND PERCEIVED EXTERNAL PRESTIGE ON ORGANIZATIONAL IDENTIFICATION
}

ALE SMIDTS, CEES B.M. van RIEL \& AD Th.H. PRUYN

Erasmus Research Institute of Management

\author{
Erasmus University \\ P.O. Box 1738 \\ 3000 DR Rotterdam \\ The Netherlands \\ Tel: +31-10-4081917 \\ Fax: +31-10-2120544 \\ e-mail: asmidts@fbk.eur.nl
}




\title{
THE IMPACT OF EMPLOYEE COMMUNICATION AND \\ PERCEIVED EXTERNAL PRESTIGE \\ ON ORGANIZATIONAL IDENTIFICATION
}

\begin{abstract}
Employees' Organizational Identification (OI) is measured in a customer service organization. Particularly the effects of employee communication and perceived external prestige (PEP) on OI were evaluated. Results show that employee communication affects OI more strongly than PEP. One aspect of employee communication, the communication climate, appears to play a central role: it mediates the impact on OI of the content of employee communication. These results suggest that the importance of how an organization communicates internally is even more vital than the question what is being communicated. Consequences of the results for managing and synchronizing internal and external communication are discussed.
\end{abstract}


Employees who identify strongly with their organization are more likely to show a supportive attitude toward it (Ashforth \& Mael, 1989), and to make decisions that are consistent with organizational objectives (Simon, 1997: 284). Organizational identification may induce employees to behave in accordance with the company's identity, reputation and strategy (Ashforth \& Mael, 1996). Such behaviors are particularly important in services organizations, where employees play a vital role in delivering quality and in achieving customer satisfaction (Zeithaml \& Bitner, 1996: 304-305). It has indeed been shown that strong identification on the part of employees may positively contribute to a company's success (Mathieu \& Zajac, 1990; Randall, 1990) and may explain the superior and sustained performance of some corporations (Hunt, Wood and Chonko, 1989). Hence, organizations should engender identification to facilitate their functioning (Cheney, 1983; Pratt, 1998).

In selecting appropriate tools to enhance identification, managers should know their employees' needs and motivations for identification with the organization. From social identity theory (see e.g. Tajfel, 1982), two basic motives for identification can be derived (Pratt, 1998): (a) the need for self-categorization (Turner, 1987) which requires the differentiation between ingroup and outgroup, and (b) the need for self-enhancement which requires that group membership is rewarding. The first motive involves clarifying ingroup/outgroup boundaries, which may help defining "the individual's place in society" (Tajfel, 1981: 255). The fulfillment of the latter motive can be established by associating oneself with a successful organization (Fisher \& Wakefield, 1998) and would seem to be dependent on the attractiveness (Dutton, Dukerich and Harquail, 1994) or the (perceived) prestige of the organization (Mael \& Ashforth, 1992). Self-enhancement is also achieved when members feel acknowledged in an organization that they 
appreciate. Managing social (or organizational) identification would thus require an instrument that (a) facilitates the categorization process (Turner, Oakes, Haslam \& McGarthy, 1994) and/or (b) enhances the perceived value of group membership by emphasizing "positive group distinctiveness" (Pratt, 1998). We consider communication to be a crucial and feasible management instrument to affect these underlying motives for identification. Important questions in this respect are how and what to communicate to employees.

Recently, Fisher and Wakefield (1998) have recommended different communication strategies for successful and unsuccessful organizations to strengthen members' identification. Less successful organizations, whose members cannot easily 'bask in reflected glory' (Cialdini et al., 1976), should increase members' involvement with the company mission and/or invest in strengthening the emotional bonds between members, whereas successful companies should emphasize their victories. Managers should thus make decisions about either to communicate their companies' successes (often attained by means of external communication) or to emphasize the intrinsic qualities of the organization for its members (by means of internal communication).

With the instrument of external communication, managers can influence the company's external prestige as perceived by employees. Generally speaking, information about the company will enhance the identification with the organization because it adds to its visibility and distinctiveness and increases employees' awareness of being a member of that organization (the categorization process). Particularly with positively valued information, members feel proud to be part of a well-respected company, as it strengthens their feelings of self-worth (Mael \& Ashforth, 1992; Dutton et al., 1994; Bhattacharya, Rao \& Glynn, 1995) and thus 
serves the self-enhancement motive. Similarly, members may feel discontented with belonging to a company with a negative reputation, which can result in looser (psychological) ties with the organization. The organization's perceived external image is therefore a significant factor in influencing organizational identification.

An instrument that has rather been neglected in organizational identification literature, is internal (or employee) communication. Employee communication may help organizational members to identify with their company by transmitting messages conveying the goals, values and achievements of the organization and by providing information in the form of guidelines for individual and collective action (Cheney, 1983). The content of such information discloses the organization's identity to its members, and thereby facilitates the categorization process. According to Dutton et al. (1994; see also Dutton \& Dukerich, 1991; Bhattacharya et al., 1995), exposure to the organization's identity is fundamental to group identification.

Also the communication climate (or how the information is communicated in the organization) is important to identification. A positive climate will increase the attractiveness of the organization. Lawler (1989), for example, has stated that the management of communication openness is one of the easiest and most effective ways to foster employee involvement within organizations, and thus the perceived value of group membership.

The purpose of this paper is to understand how communication can be employed by managers to improve organizational identification. More specifically, we will demonstrate that employee communication adds to the explanation of organizational identification, in addition to the effect of perceived external prestige. Furthermore, we investigate how two dimensions of employee communication, the content and the climate, affect identification. Hypotheses were developed and subsequently tested in 
an organization dealing with financial services. Social identity theory was taken as the starting point in the construction of our conceptual model.

\section{CONCEPTUAL BACKGROUND}

Organizational Identification (OI) is concerned with the perception of 'oneness' with the organization (Ashforth \& Mael, 1989; Mael \& Ashforth, 1992). The construct has firm roots in social identity theory (Tajfel, 1978; Tajfel \& Turner, 1979) and is defined as the 'cognition of membership of a group and the value and emotional significance attached to this membership' (Tajfel, 1978: 63). In this definition two elements can be distinguished:

(1) A cognitive component of identification, which reflects the perceived amount of shared interests between the individual and the organization (Ashforth \& Mael, 1989; Mael \& Ashforth, 1992). It conveys the extent to which an individual perceives him/herself as belonging to the group, being intertwined with the fate of the group, and being a typical member of it. The cognitive component is of particular relevance when employees are to define the boundaries between ingroup and outgroup, in order to accomplish self-categorization.

(2) An affective component (feelings of pride of belonging to the organization or feeling acknowledged in the organization), which is important in the creation of a positive image of the own organization or to "achieve positive social identity" (Tajfel, 1982, p.24). This component is strongly related to the self-enhancement motive.

In the social identity research tradition (e.g. Brown et al., 1986; Doosje, Ellemers \& Spears, 1995) both components are indeed incorporated in the measurement of social identification. Unfortunately, in one of the most often cited scales in OI 
literature (Ashforth and Mael, 1989; see also Mael \& Ashforth, 1992) the affective component was deliberately not included. Other OI experts (e.g. Dutton et al., 1994), however, do seem to acknowledge that emotional binding with the organization is of major importance in the construction of a positive self-identity. Affect should therefore be considered an essential element of organizational identification (Hinkle, Taylor, Fox-Cardamone \& Crook, 1989; Harquail, 1998; Ellemers, Kortekaas \& Ouwerkerk, 1999). In order to foster OI by means of communication one may thus emphasize either cognitive or affective ties with the organization, or both.

In the conceptual model (Figure 1), organizational identification is proposed to be influenced by two employee communication dimensions (the content of communication and the communication climate), and by the perceived external prestige. Regarding the content of communication two levels are distinguished: information received about one's own role in the organization and information about the organization. We first discuss the proposed relationship between OI and perceived external prestige.

\section{Perceived External Prestige and Organizational Identification}

Perceived External Prestige (PEP) represents how employees think outsiders view the organization (and thus themselves as a member thereof). PEP (or the 'construed external image' of the organization (Dutton et al., 1994)) may result from various sources of information, such as word-of-mouth, publicity, external companycontrolled information and even internal communication about how the company is perceived by outsiders. Several authors have proposed that PEP affects OI (see e.g. Mael \& Ashforth, 1992; Pratt, 1998). Essentially, members may feel proud to belong to 
an organization that is believed to have socially valued characteristics (Dutton et al., 1994), and may feel inclined to 'bask in its reflected glory' Cialdini et al., 1976). This is expected to occur the most strongly when members believe that important outsiders (such as customers, shareholders or the general public) see the organization in a positive light. Mael and Ashforth (1992), Bhattacharya et al. (1995) and Fisher and Wakefield (1998) have indeed found a significant effect of perceived external prestige on organizational identification. They noted that individuals identify with a group partly to enhance their self-esteem: the more prestigious the organization is perceived, the greater the potential boost to self-esteem through identification. Thus,

Hypothesis 1. The higher the perceived external prestige of their organization, the stronger members will identify with it.

\section{Employee Communication and Organizational Identification}

Employee communication is defined here as 'the communication transactions between individuals and/or groups at various levels and in different areas of specialization that are intended to design and redesign organizations, to implement designs and to coordinate day-to-day activities' (Frank \& Brownell, 1989: 5-6). Employee communication is generally seen as a multidimensional construct. Employees are not merely satisfied or dissatisfied with communication in general, but can express varying degrees of satisfaction about definite aspects of communication (Clampitt \& Downs, 1993: 6). Regarding OI, particularly two components of employee communication are pertinent antecedents (see Figure 1): (a) The content of organizational messages as it concerns members' satisfaction with what is being communicated, and (b) the communication climate, consisting of openness and trust in 
communication, the experience to have a say in the organization and supportiveness (the feeling that one is being taken seriously). The proposed impact of each of these components on OI is discussed below.

insert Figure 1 about here

(a) The content of employee communication. Whereas social categorization would require that employees receive adequate information about what is central and distinctive about their organization, self-categorization (Turner, 1987) can be facilitated when employees are provided with useful information about their role in the organization. We therefore distinguish between communication about how the organization deals with relevant organizational issues and communication about one's personal contribution to the company's success.

Being well-informed about organizational issues (such as goals and objectives, new developments, activities and achievements) will enable members to discover the salient characteristics that distinguish this organization from others (Dutton et al., 1994; Pratt, 1998), and thus enhance social categorization. By this, the ingroup will become more transparent as an object with which to identify. Furthermore, mere exposure to information about the own organization will increase the perceived attractiveness of the organization (Zajonc, 1980), and thus may reassure members that they work for an organization that is worth being associated with. In organizations that are perceived favorably by their members, organizational identification is more likely to occur (Dutton et al., 1994; Pratt, 1998), because it enhances members' feelings of self-worth. We therefore propose,

Hypothesis 2. The more adequate the information employees receive about their company, the stronger their identification with the organization. 
With respect to information about the personal role in the organization, we propose that if employees receive useful and sufficient information about what is expected of them in their work and regarding their contribution, this will increase the understanding of norms and values of respected membership. Not only will such information provide the basis for self-categorization (Turner et al., 1994; Hogg, 1996), but it will it also enhance members' senses of belonging to and involvement with the organization (Lawler, 1989) and hence strengthen their identification. Thus,

Hypothesis 3. The more adequate the information employees receive on their personal role in the company, the stronger their identification with the organization.

(b) Communication climate. The communication climate can be seen as a facet of the broader construct of 'organizational climate' (Falcione, Sussman, \& Herden, 1987). Communication climate is distinguished from organizational climate in that it includes only communicative elements, for example, judgments on the receptivity of management to employee communication or the trustworthiness of information being disseminated in the organization Guzley, 1992). The communication climate is an important aspect in all communication audits (Downs, 1988). Relevant dimensions are (Redding, 1972; Dennis, 1975; Trombetta and Rogers, 1988): openness and trust (candor) in communication, the perceived participation in decision making (or the feeling of having a voice in the organization), and supportiveness (or the feeling of being taken seriously).

We expect that a more positive communication climate will increase members' identification with the organization. Some indications for this effect can be derived from studies by Trombetta and Rogers (1988) and Guzley (1992), who found that a satisfying 
communication climate positively affects members' involvement with and loyalty to the organization. Other studies showed that both openness of (top) management and involvement in organizational decision making increase trust in management (Mishra \& Morrissey, 1990; McCauley \& Kuhnert, 1992; Meznar \& Nigh, 1995) and may even increase profit and productivity (Rosenberg \& Rosenstein, 1980).

A positive communication climate will strengthen identification, because it is rewarding and thus serves members' self-enhancement. It invites employees to participate actively in discussions about organizational issues and involves them in decision making. Moreover, openness in the communication with supervisors and colleagues may add to one's feelings of self-worth, because under such conditions members will experience that they are being taken seriously. We therefore propose

Hypothesis 4. The more positive the communication climate is evaluated by employees, the stronger they will identify with their organization.

As is shown in the model (Figure 1), we expect that the communication climate may be an important mediating variable in the relationship between the content of employee communication and OI. More specifically, receiving adequate information about one's own role and the achievements of the organization may positively affect the communication climate. Evidently, lack of information (or perceived lack of information) disables members to be aware of the organizational goals and objectives or to be involved in organizational decision making. Nor will this contribute to one's feelings of being taken seriously. Adequate information on the content level is thus supposed to be a sine qua non for a positive appraisal of the communication climate and hence for organizational identification. In this study, we will explore to what extent the communication climate mediates the effects of the content of employee communication on OI. 


\section{METHOD}

Subjects and procedure. Data were collected in a large customer services organization. The organization consists of a headquarters and fifteen local offices. A two-stage sampling procedure was applied. In the first stage, 15 organizational units were selected: 6 departments within headquarters, 8 local offices and one office servicing customers abroad. The last mentioned office has a special position in the organization because of the distinct procedures involved in dealing with customers abroad. In the second stage, a stratified random sample of $n=775$ employees was drawn from the selected units. Employees were divided into two strata with regard to their function: management/staff vs. operating/front-line personnel.

Employees received an introductory letter and questionnaire at their home address. Great emphasis was put on assuring the anonymity of response. A follow-up letter was sent to augment the response. Overall response percentage was $52 \%(n=402)$ which is quite high given the length of the questionnaire. The response of managers/staff $(64 \% ; n=138)$ was somewhat higher than that of the operating and front-line personnel $(47 \% ; n=264)$. No difference showed up in response rate between local offices and headquarters; the response rate of the office dealing with customers abroad was somewhat lower, however.

Sixty percent of the respondents is between 30 and 45 years of age, $24 \%$ is younger than 30 years and $16 \%$ is older than 45 years. Almost half of the respondents (48\%) has already worked with this organization for more than ten years, $24 \%$ has worked there between five and ten years and $28 \%$ less than five years. Thus, with regard to function, age and tenure, a diverse and representative sample of respondents was interviewed. 
Measures. An organizational identification scale was developed consisting of five items (measured on 5-point disagree/agree scales). The selection of items was based on the concept of social identity (Tajfel, 1978) and on existing scales in the literature (Cheney, 1983; Brown et al., 1986; Hinkle et al., 1989; Abrams, 1992; Doosje et al., 1995). The scale includes both cognitive and affective elements (see Appendix A). Confirmatory factor analysis (Jöreskog and Sörbom, 1993) showed that the scale is unidimensional $\left(\chi^{2}(5)=14.57, p>.012 ; \mathrm{CFI}=.99 ; \mathrm{TLI}=.97\right.$; RMSEA $\left.=.070\right)$ and reliable (Cronbach $\alpha=.84$ ). Discussions of these indices can be found in Bentler (1990) and Brown \& Cudeck (1993).

Perceived external prestige (PEP) was based on Mael and Ashforth's (1992) organizational prestige scale and operationalized by means of four items. Sample items are: 'Our organization has a good reputation', and 'Our organization is looked upon as a prestigious company to work for'. The items were rated on 5-point disagree/agree scales. A unidimensional and reliable scale was found $\left(\chi^{2}(2)=3.96, p>.014 ;\right.$ CFI $=.99$; TLI $=$ $.98 ;$ RMSEA $=.050 ;$ Cronbach $\alpha=.76)$.

In order to measure employee communication in an organization, so-called communication audits have been developed (see Greenbaum, Clampitt \& Willihnganz, 1988, for an overview). Five auditing instruments appear to be popular: the Organizational Communication Questionnaire (OCQ) by Roberts \& O'Reilly (1974), the LTT Communication Audit Questionnaire by Wiio \& Helsila (1974), the Communication Satisfaction Questionnaire by Downs \& Hazen (1977), the ICA Communication Audit by Goldhaber \& Rogers (1979), and Hamilton's (1987) Communication Audit. These audits were used as the main source of reference for the selection of items representing three dimensions of employee communication distinguished in the model: 
(1) The adequacy of information on organizational issues was operationalized by means of nine, organization-specific items. Two sample items are: 'About the goals of our organization, I receive ... information' and 'About how customers evaluate our services, I receive ... information'. Respondents had to rate these items with respect to both sufficiency and usefulness on 5-point semantic differential scales. Factor analysis confirmed the unidimensionality for both dimensions. For each dimension, composite scales were created (sufficiency: Cronbach $\alpha=.89$; usefulness: $\alpha=.91$ ).

(2) The adequacy of information that employees receive regarding their personal role was operationalized by means of four statements. Two sample items are: 'About what they expect from me, I get ... information' and 'About how I perform my job, I receive ... information'. Again, these items were rated with respect to sufficiency and usefulness, and appeared to be unidimensional. Composite scales were created (sufficiency: $\alpha=.75$; usefulness: $\alpha=.78$ ). Confirmatory factor analysis revealed that organizational information adequacy and personal information adequacy are indeed separate factors (the hypothesis of one common factor is rejected in a Chi-square difference test: $\left.\chi_{\mathrm{d}}^{2}(1)=158, p<.001\right)$.

(3) Communication climate was measured by 15 statements selected from existing instruments (Dennis, 1975; Alutto \& Vredenburgh, 1977; Downs \& Hazen, 1977; Falcione et al., 1987). The items represent the dimensions: (i) trust and openness in communication (upward, downward, horizontal), (ii) participation in decision making (or to have a say in the organization), and (iii) the feeling that one is being taken seriously by other members of the organization (supportiveness). Sample items are: 'My superiors (colleagues, subordinates) are open and honest towards me', 'In this organization, we have ample opportunity to have our say' and 'Other members pay careful attention to what I have to say in this organization'. The items were rated on 5-point disagree/agree 
scales. Although three separate dimensions were anticipated, in exploratory factor analysis four mutually correlated dimensions were found. The dimension of openness and trust appeared to split with respect to communication with either (top)-management or direct colleagues and supervisors. Confirmatory factor analysis revealed that a second order latent factor ('communication climate') adequately represents the four dimensions $\left(\chi^{2}(2)=6.78, p>.034 ; \mathrm{CFI}=.99 ; \mathrm{TLI}=.96 ; \mathrm{RMSEA}=.079 ;\right.$ Cronbach $\left.\alpha=0.76\right)$. Thus, composite scales were created for each of these four dimensions and used in further analysis as indicator of communication climate.

In order to investigate the discriminant validity of the OI scale, we also included a measure of overall job satisfaction. This scale is a subscale of the Michigan Organizational Assessment Questionnaire (see Spector, 1997: 19). The three items are: 'All in all I am satisfied with my job', 'In general, I don't like my job' and 'In general, I like working here' $(\alpha=.80)$. Confirmatory factor analysis showed that OI and job satisfaction indeed are separate, though correlated constructs $\left(\chi_{\mathrm{d}}^{2}=92.1 ; p<.001\right)$.

\section{RESULTS}

\section{Descriptive Statistics}

Table 1 provides an overview of the measured constructs. For reasons of comprehensibility, composite scores for OI, communication climate (CC) and PEP are presented. On average, the strength of identification in this organization is slightly above the midpoint of a five-point scale $(M=3.23)$. Regarding the antecedents of OI, the prestige of the organization is perceived as significantly more positive than the internal communication climate $(M=3.45$ vs. $M=3.15 ; t=8.29, p<.001)$; both scores differ 
significantly from the OI score $(p<.001$ and $p<.021$, respectively). Employees appear to be relatively better informed about their own role than about company issues $(M=$ 3.30 and $M=2.94$, respectively; $t=10.7, p<.001)$.

insert Table 1 about here

Some indications that support the validity of the OI-scale can be given. First, substantial variation in OI-scores was found, indicating that the scale successfully discriminates between employees. Second, and as was expected (Mathieu \& Zajac, 1990), OI differs per job level: managers and staff appear to identify significantly stronger with the organization than operating and front-line personnel do $\left(M_{\mathrm{mngt}}=3.48\right.$ vs. $M_{\mathrm{oper}}=3.19 ;$ MANOVA: $\left.F=7.12, p<.001\right)$. Furthermore, the strength of organizational identification tends to be highest at headquarters, lowest at the 'foreign' office and in between these values at the local offices (MANOVA: $F=1.97, p<.08$ ). Physical distance thus seems to create a lower psychological attachment to the organization. Organizational tenure does not appear to have a significant effect on OI $(M A N O V A: F=1.33, p=.21)$.

\section{Test of the Model}

Structural equation modeling (Bollen, 1989) was performed in order to deal adequately with the multiple indicator measurement of the constructs and to estimate direct and indirect effects. Parameter estimates were obtained by means of LISREL 8 (Jöreskog and Sörbom, 1993). The covariance matrix was taken as the input for the analysis ( $n=388$, due to listwise deletion of missing values). 
Figure 2 shows the results. In this figure, circles represent latent variables whereas boxes represent their indicators (i.e. items). Organizational identification is shown to be affected by three latent variables describing employee communication and one latent factor describing perceived external prestige (PEP). Two or more indicators assess each latent variable. In Figure 2, standardized regression coefficients are presented with $t$-values in brackets. Only paths that are significant at $p=0.05$ (twotailed; $t_{0.05}=1.96, n=388$ ) are shown in this diagram. The relative importance of the variables is reflected by the magnitude of the coefficients. The overall fit of the model is good: $\chi^{2}(109)=291.8, p>.001 ; \mathrm{GFI}=0.92 ; \mathrm{CFI}=.94 ; \mathrm{TLI}=.93 ; \mathrm{RMSEA}=.066$. The overall fit measures, the $R$-squares of the separate variables, the correct signs and significance of the path coefficients, all indicate that the model fits the data well. The absence of direct effects of both personal and organizational information adequacy on OI indicates that the communication climate fully mediates the impact of information content on OI. That is to say, direct effects of these antecedents on OI become nonsignificant if the communication climate is included as a mediator in the model.

insert Figure 2 about here

The findings show that organizational identification is explained quite well $\left(R^{2}=\right.$ .61). Organizational identification is affected both by employee communication variables and perceived external prestige. If employees perceive their organization to be evaluated positively by external reference groups (PEP), this will enhance their strength of identification $\beta=.42, p<.001)$. Thus, as was predicted in Hypothesis 1 , there is indeed an effect of 'basking in reflected glory'. Also, and as was predicted in Hypothesis 4, the strength of identification appears to be influenced strongly by the communication climate $(\beta=.52, p<.001)$. This means that a communication climate that is open, in 
which the employee feels to be taken seriously by (top) management and co-workers, and in which (s)he feels to have a voice, increases the identification with the organization. Comparing the magnitudes of these effects indicates that the effect of CC on OI is significantly larger than the effect of PEP on OI (Chi-square difference test: $\chi_{d}^{2}$ $(1)=4.17, p<.041)$.

In addition to these direct effects on OI, two indirect relationships manifest themselves. The adequacy of the information the employee receives about his/her personal role (Hypothesis 2) substantially affects identification through the communication climate. The standardized total effect on OI is 0.28 (.53 x .52; see e.g. Bollen (1989) for rules of calculation of effects). The second indirect relationship concerns the effect of the adequacy of the information the employee receives about the organization (Hypothesis 3) on OI, again through the communication climate (total effect on OI: $0.21(.41 \times .52))$. Thus Hypotheses 2 and 3 are both confirmed with respect to the supposed influences on OI. The effects, however, must be qualified by the intermediary role of communication climate.

Communication climate is strongly affected by the adequacy of personal and organizational information $\left.R^{2}=.75\right)$. The effect of personal information adequacy seems somewhat larger $(\beta=.53)$ than the effect of organizational information $(\beta=.41)$, but this difference is not significant $(p>.80)$.

To summarize: with regard to the effects of perceived external prestige and communication climate on OI, hypotheses $\mathrm{H} 1$ and $\mathrm{H} 4$ are both confirmed. With regard to the effect of the communication content on OI, hypotheses $\mathrm{H} 2$ and $\mathrm{H} 3$ are conditionally supported. Their effect is mediated by the communication climate. 


\section{DISCUSSION}

In this study, we explored the relationships between identification, perceived external prestige and employee communication. Employee communication is considered an important internal management tool to affect the performance of employees by means of increasing organizational identification. Social identity theory served as reference for our theoretical framework and propositions (Tajfel, 1978; Dutton et al., 1994; Pratt, 1998).

A main contribution of this study is that it shows that employee communication adds to our understanding of the identification strength of employees with their organization, in addition to the role of perceived external prestige. The effect of PEP on OI shows that the self-enhancement motive is active: Employees eagerly identify with an organization that is believed to be positively evaluated by outsiders. This finding confirms the results of other studies (Mael \& Ashforth, 1992; Bhattacharya et al., 1995; Fisher \& Wakefield, 1998).

As regards employee communication, our findings show that the communication climate is the most important communication antecedent of OI. This, again, indicates that self-enhancement motives are strongly related to identification: Feelings of self-worth seem to be enhanced under conditions of openness, trust and appreciated participation in communication. Categorization motives would appear to be less pertinent. This can be inferred from our finding that being adequately informed about organizational matters and one's own role in the organization only indirectly affects OI through the communication climate.

Our findings suggest that the importance of how an organization communicates internally is even more vital than the question what is being communicated. This implies 
that communication aspects that are usually considered to be rather 'soft', such as openness, trust and having a say in the organization, are indeed both relevant and 'hard' factors when it comes to organizational identification. On the presumption that identification affects the performance of employees and thus also the business performance, an attractive communication climate could prove to contribute significantly to the (long-term) success of the organization. Managers should therefore pay serious attention to the communication climate in their organization by providing their employees the opportunity to speak out, get involved, be listened to and participate actively. The communication climate can even be seen as an equity that requires investments such as one might, for example, invest in a (corporate) brand. Improving the communication climate therefore demands a continuous and long-term management commitment.

Nevertheless, providing relevant information (the content of communication) is an obvious sine qua non in order to establish any identification with the organization. If members perceive that the organization is seriously attempting to inform them adequately on relevant issues, they will more readily heed and act on that information.

The impact of the perceived external prestige on organizational identification provides another tool for management. As it has been shown that the perceived prestige is quite strongly related to identification, management should consider the following courses of action: (1) to positively enhance the corporate reputation by means of external communication. Besides the effect on external stakeholders, visibility of the organization through corporate communication and attractive advertising will also have an impact on members' perceptions of their company and may eventually evoke pride on the part of the employee; (2) to internally disseminate any positive information about the company as it is communicated externally. Conversely, a strong OI may help management to 
counteract (unjustified) negative publicity because it evokes positive in-group biases (e.g. Brewer, 1979).

This study implies that both external communication (through its effects on perceived external prestige) and internal communication may affect organizational identification. Internal communication is relatively strongly related to OI. An advantage of this instrument is that organizational members have only a limit degree of freedom to ignore corporate messages. Dutton et al. (1994) have stressed the relevance of such 'unavoidable exposure' for OI. Managers should realize, however, that improving e.g. the internal communication climate would need a long lasting commitment from many persons in the organization.

Influencing OI by means of external communication is perhaps less easy to accomplish, since the impact of PEP on OI is smaller than that of internal communication. Improving PEP through external communication may only be manageable if there is ample positive information on the company. Fisher and Wakefield (1998) have also proposed that an external communication strategy will only be suitable for successful companies, whereas for less successful companies one would advise to employ strategies to improve internal relationships. Moreover, PEP is not solely influenced by (company controlled) external communication, but is also affected by information sources which are beyond company control. Since it has been shown that autonomous external sources have a greater impact on the perceived external prestige than company controlled communication (cf. Farmer, Slater \& Wright, 1998), such information may either amplify or neutralize the company's communication efforts. 


\section{Limitations and Further Research}

In this study, we estimated a causal model on cross-sectional data. Although this is accepted practice, care has to be taken not to overinterpret the results with regard to causality. Also, with self-report measures, one cannot entirely rule out the possibility of common method bias that may have augmented the relationships between constructs. However, considering the relatively large sample, the extensive measures, the evidence of separate constructs provided by CFA's, the highly motivated respondents and the plausible relationships that we found between constructs, our study seems to provide evidence that the quality of employee communication and the perceived external prestige are strongly related to organizational identification. Further research should establish the causal claim underlying our model that employee communication is indeed a tool to influence the strength of identification. To this end, field experiments and longitudinal designs may be applied. Such designs may, for example, be more conclusive about possible alternative explanations for our results (e.g. that strong identifyers may be subject to ingroup biases and hence will be more positive about their organizations' communication climate and PEP).

This study reports data that were collected in only one organization (although employees were sampled from 15 different business units). This may impose some restrictions on the generalizability of the reported strength of paths in the model. I.e., in other organizations PEP might well prove to be relatively more important in strengthening OI. Such an effect can be anticipated in organizations with highly visible and reputed corporate brands. One may also hypothesize that in relatively young and fast growing organizations with many newcomers, the content of communication will have 
stronger impact on OI, since in such organizations employees will experience stronger needs for social and self-categorization. The effect of these and other moderator variables should be studied in further research.

Another issue for further research concerns the extent to which OI affects the individual's communication behavior within the organization. Dutton et al. (1994) have proposed that stronger identification induces members to increase contact with the organization. Their proposition is grounded in Festinger's theory of cognitive dissonance: organizational members are expected to maintain consistency between their attitudes (towards the organization) and their (communication) behavior. Alternatively, one may assume that the stronger members identify with their organization, the more they will feel the obligation to respond to internal information by increasing their own communication efforts. Thus, equity (Homans, 1961) or reciprocity (Cialdini, 1993) can be established. More research is needed to assess the effects of OI on the individual's communication efforts and content. It is of particular interest to study the effects of members' communication efforts on the communication climate, and thus on the identification process of fellow members (and newcomers). Such research would require a more dynamic approach with regard to the relationship between OI and (internal) communication.

Also, more research is required on how to manage identification by manipulating the content of information. Identification concerns the incorporation of organizational attributes into the self-identity (Dutton et al., 1994). It is therefore of great importance for management to identify the dimensions which make up the company's identity, and to select the subset of attributes which should particularly be incorporated by employees in their categorization process (this subset may even vary per organizational unit). Managers can influence the identification process by exposing members to the preferred 
dimensions of identity through internal communication. For example, if one decides that innovativeness is a core attribute of the company, management should encourage employees to define themselves as innovative (and behave accordingly). Such a strategy requires careful planning in order to establish concord between the company's core strategic issues and identity attributes to be stressed in communication. To identify the attributes that need special attention in internal communication, the gaps between core organizational characteristics and identity characteristics of members must be assessed. To this end, an instrument of $\mathrm{OI}$ is required which measures the (dis)similarity between employee and organization on the attribute level (cf. Bergami \& Bagozzi, 1999). A measure of the similarity between the individual and the organization may also enable one to test the hypothesis that congruence moderates the relationship between communication and OI: when there is a high level of agreement, communication would be positively related to OI, but when there is a low level of agreement, the relationships would be negative. In the current study, employees appeared to wholeheartedly agree with both the goals $(94.4 \%)$ and means to achieve these goals (78.4\%). These numbers indicate that in this organization relatively high congruence exists, suggesting that a positive relationship between employee communication and OI could indeed by expected.

\section{REFERENCES}

Abrams, D. 1992. Processes of social identification. In G.M. Brakwell (Ed.), Social psychology of identity and the self-concept: 57-100. San Diego: Academic Press.

Alutto, J.A., \& Vredenburgh, D.J. 1977. Characteristics of decision participation by nurses. Academy of Management Journal, 20: 341-347. 
Ashforth, B.E., \& Mael, F.A. 1989. Social identity and the organization. Academy of Management Review, 14 (1): 20-39.

Ashforth, B.E., \& Mael, F.A. 1996. Organizational identity and strategy as context for the individual. In J.A.C. Baum \& J.E. Dutton (Eds.), Advances in strategic management, Volume 13: 19-64. London: JAI Press.

Bentler, P.M. 1990. Comparative fit indixes in structural models. $\underline{\text { Psychological }}$ Bulletin, 107: 238-246.

Bergami, M., \& Bagozzi, R.P. 1999. Self-categorization and commitment as distinct aspects of social identity in the organization: Conceptualization, measurement, and relation to antecedents and consequences. Working paper, The University of Michigan Business School, Ann Arbor, MI.

Bhattacharya, C.B., Rao, H., \& Glynn, M.A. 1995. Understanding the bond of identification: An investigation of its correlates among art museum members. Journal of Marketing, 59: 46-57.

Bollen, K.A. 1989. Structural equations with latent variables. New York: Wiley.

Brown, R., Condor, S., Mathews, A., Wade, G., \& Williams, J. 1986. Explaining intergroup differentiation in an industrial organization. Journal of Occupational Psychology, 59, 273-286.

Brown, M.W., \& Cudeck, R. 1993. Alternative ways of assessing model fit. In K.A. Bollen \& J.S. Long (Eds.), Testing strutural equation models: 136-162. Newbury Park, CA: Sage.

Brewer, M. B. 1979. In-group bias in the minimal intergroup situation: A cognitivemotivational analysis. Psychological Bulletin, 86 (2): 307-324.

Cheney, G. 1983. The rhetoric of identification and the study of organizational communication. Quarterly Journal of Speech, 69: 143-158. 
Cialdini, R.B. 1993. Influence: Science and practice. New York: HarperCollins.

Cialdini, R.B., Borden, R.J., Thorne, A., Walker, M.R., Freeman, S., \& Sloan, L.R. 1976. Basking in reflected glory: Three (football) field studies. Journal of Personality and Social Psychology, 34: 366-375.

Clampitt, P.G., \& Downs, C.W. 1993. Employee perceptions of the relationship between communication and productivity: A field study. Journal of Business Communication, 30 (1): 5-28.

Dennis, H.S. 1975. The construction of a managerial communication climate inventory for use in complex organizations. Paper presented at the annual convention of the International Communication Association, Chicago.

Doosje, B., Ellemers, N., \& Spears, R. 1995. Perceived intragroup variability as a function of group status and identification. Journal of Experimental Social Psychology, 31, 410-436.

Downs, C.W. 1988. Communication audits. IL: Scott Foreman.

Downs, C.W., \& Hazen, M.D. 1977. A factor analytic study of communication satisfaction. Journal of Business Communication, 14 (3): 63-73.

Dutton, J.E., \& Dukerich, J.M. 1991. Keeping an eye on the mirror: Image and identity in organizational adaptation. Academy of Management Journal, 34 (3): 517-554.

Dutton, J.E., Dukerich, J.M., \& Harquail, C.V. 1994. Organizational images and member identification. Administrative Science Quarterly, 39 (2): 239-263.

Ellemers, N., Kortekaas, P., \& Ouwerkerk, J.W. 1999. Self-categorisation, commitment to the group and group self-esteem as related but distinct aspects of social identity. European Journal of Social Psychology, 29: 371-389. 
Falcione, R.L., Sussman, L., \& Herden, R.P. 1987. Communication climate in organizations. In F.M. Jablin, et al. (Eds.), Handbook of organizational communication: 195-228. Newbury Park: Sage.

Farmer, B.A., Slater, J.W., \& Wright, K.S. 1998. The role of communication in achieving shared vision under new organizational leadership. Journal of Public Relations Research, 10 (4): 219-223.

Fisher, R.J., \& Wakefield, K. 1998. Factors leading to group identification: A field study of winners and losers. Psychology \& Marketing, 15 (1): 23-40.

Frank, A., \& Brownell, J. 1989. Organizational communication and behavior: Communicating to improve performance. Orlando, Florida: Holt, Rinehart and Winston.

Goldhaber, G., \& Rogers, D.P. 1979. Auditing organizational communication systems: The ICA communication audit. Dubuque: Brown Publishers.

Greenbaum, H.H., Clampitt, P., \& Willihnganz, S. 1988. Organizational communication: An examination of four instruments. Management Communication Quarterly, 2 (2): 245-282.

Guzley, R.M. 1992. Organizational climate and communication climate: Predictors of commitment to the organization. Management Communication Quarterly, 5 (4): $379-402$.

Hamilton, S. 1987. A communication audit handbook. New-York: Longman.

Harquail, C.V. 1998. Organizational identification and the "whole person": Integrating affect, behavior, and cognition. In D.A. Whetten \& P.C. Godfrey (Eds.), Identities in organizations: Building theory through conversations: 223-231. Thousand Oaks: Sage Publications. 
Hinkle, S., Taylor, L.A., Fox-Cardamone, D.L., \& Crook, K.F. 1989. Intragroup identification and intergroup differentiation: A multicomponent approach. $\underline{\text { British }}$ Journal of Social Psychology, 28: 305-317.

Hogg, N. 1996. Social identity, self-categorization, and the small group. In J. Davis \& E. Witte (Eds.), Understanding group behavior, Vol. 2: Small group processes and interpersonal relations: 227-254. Hillsdale: Lawrence Erlbaum.

Homans, G.C. 1961. Social behavior: Its elementary forms. New York: Harcourt Brace Jovanovich.

Hunt, S.D., van Wood, R., \& Chonko, L.B. 1989. Corporate ethical values and organizational commitment in marketing. Journal of Marketing, 53: 79-90.

Jöreskog, K.G., \& Sörbom, D. 1993. LISREL 8: User's reference guide. Chicago: SPSS Inc.

Lawler, E.E. 1989. With HR help, all managers can practice high-involvement management. Personnel, April: 26-31.

Mael, F., \& Ashforth, B.E. 1992. Alumni and their alma mater: A partial test of the reformulated model of organizational identification. Journal of Organization Behavior, 13: 103-123.

Mathieu, J.E., \& Zajac, D.M. 1990. A review and meta-analysis of the antecedents, correlates and consequences of organizational commitment. Psychological Bulletin, 108 (2): 171-194.

McCauley, D.P., \& Kuhnert, K.W. 1992. A theoretical review and empirical investigation of employee trust in management. Public Administration Quarterly, 16 (2): $265-284$. 
Meznar, M., \& Nigh, D. 1995. Buffer or bridge? Environmental and organizational determinants of public affairs in American firms. Academy of Management Journal, 38 (4): 975-996.

Mishra, J., \& Morrissey, M.A. 1990. Trust in employee/employer relationships: A survey of West Michigan managers. Public Personnel Management, 19 (4): 443486.

Pratt, M.G. 1998. To be or not to be? Central questions in organizational identification. In D.A. Whetten \& P.C. Godfrey (Eds.), Identities in organizations: Building theory through conversations: 171-207. Thousand Oaks: Sage Publications.

Randall, D. 1990. The consequences of organizational commitment: Methodological investigation. Journal of Organizational Behavior, 11: 361-378.

Redding, W.C. 1972. Communication within organization: An interpretive review of theory and research. New York: Industrial Communication Council.

Roberts, K.H., \& O'Reilly, C.A. 1974. Measuring organizational communication. Journal of Applied Psychology, 59 (3): 321-326.

Rosenberg, R.D., \& Rosenstein, E. 1980. Participation and productivity: An empirical study. Industrial and Labor Relations Review, 33 (3): 355-367.

Simon, H.A. 1997. Adminstrative behavior: A study of decision-making processes in adminstrative organizations. New York: The Free Press.

Spector, P.E. 1997. Job satisfaction: Application, assessment, cause, and consequences. Thousand Oaks: Sage.

Tajfel, H. 1978. The achievement of group differentiation. In H. Tajfel (Ed.), Differentiation between social groups: Studies in the social psychology of intergroup relations: 77-98. London: Academic Press. 
Tajfel, H. 1981. Human groups and social categories: Studies in social psychology. New York: Cambridge University Press.

Tajfel, H. 1982. Social psychology of intergroup relations. Annual Review of Psychology, 33, 1-39.

Tajfel, H., \& Turner, J.C. 1979. An integrative theory of intergroup conflict. In W.G. Austin, \& S. Worchel (Eds.), The social psychology of intergroup relations: 33-47. Monterey, CA: Brooks/Cole.

Trombetta, J.J., \& Rogers, D.P. 1988. Communication climate, job satisfaction, and organizational commitment. Management Communication Quarterly, 4 (1): 494514.

Turner, J.C. 1987. Rediscovering the social group: A self-categorization theory. New York: Basil Blackwell.

Turner, J.C., Oakes, P., Haslam, S., \& McGarty, C. 1994. Self and collective: Cognition and social context. Personality and Social Psychology Bulletin, 20, 454-463.

Wiio, O.A., \& Helsila, M. 1974. Auditing communication in organizations: A standard survey, LTT communication audits. Finnish Journal of Business Economics, 4: 305-315.

Zajonc, R.B. 1980. Feeling and thinking: Preferences need no inferences. American Psychologist, $35,151-175$.

Zeithaml, V.A., \& Bitner, M.J. 1996. Services marketing. McGraw-Hill. 


\section{APPENDIX A}

Measurement Scale of Organizational Identification

(1) I feel strong ties with

(2) I experience a strong sense of belonging to

(3) I feel proud to work for

(4) I am sufficiently acknowledged in

(5) I am glad to be a member of 
TABLE 1

Descriptive Statistics and Correlations for Composite Variables

\begin{tabular}{lccccccccc}
\hline & Mean & s.d. & $\mathbf{1}$ & $\mathbf{2}$ & $\mathbf{3}$ & $\mathbf{4}$ & $\mathbf{5}$ & $\mathbf{6}$ & $\mathbf{7}$ \\
\hline 1. OI & 3.23 & .85 & & & & & & & \\
2. PEP & 3.45 & .70 & .54 & & & & & & \\
3. CC & 3.16 & .63 & .61 & .44 & & & & & \\
INFO ABOUT SELF: & & & & & & & & \\
4. Sufficiency & 3.29 & .84 & .43 & .28 & .61 & & & & \\
5. Usefulness & 3.30 & .82 & .46 & .30 & .61 & .79 & & & \\
INFO ABOUT & & & & & & & & & \\
ORGANIZATION: & & & & & & & & & \\
6. Sufficiency & 2.94 & .80 & .43 & .33 & .64 & .63 & .58 & & \\
7. Usefulness & 2.94 & .82 & .42 & .34 & .62 & .57 & .61 & .85 & \\
8. Job satisfaction & 3.72 & 1.01 & .67 & .36 & .48 & .31 & .37 & .33 & .31 \\
\hline
\end{tabular}

$\mathrm{N}=388$

All correlations: $p<.001$

Note: For reasons of comprehensibility, composite scores are presented here. Descriptive statistics for individual items underlying these composites are available from the authors on request. 
FIGURE 1

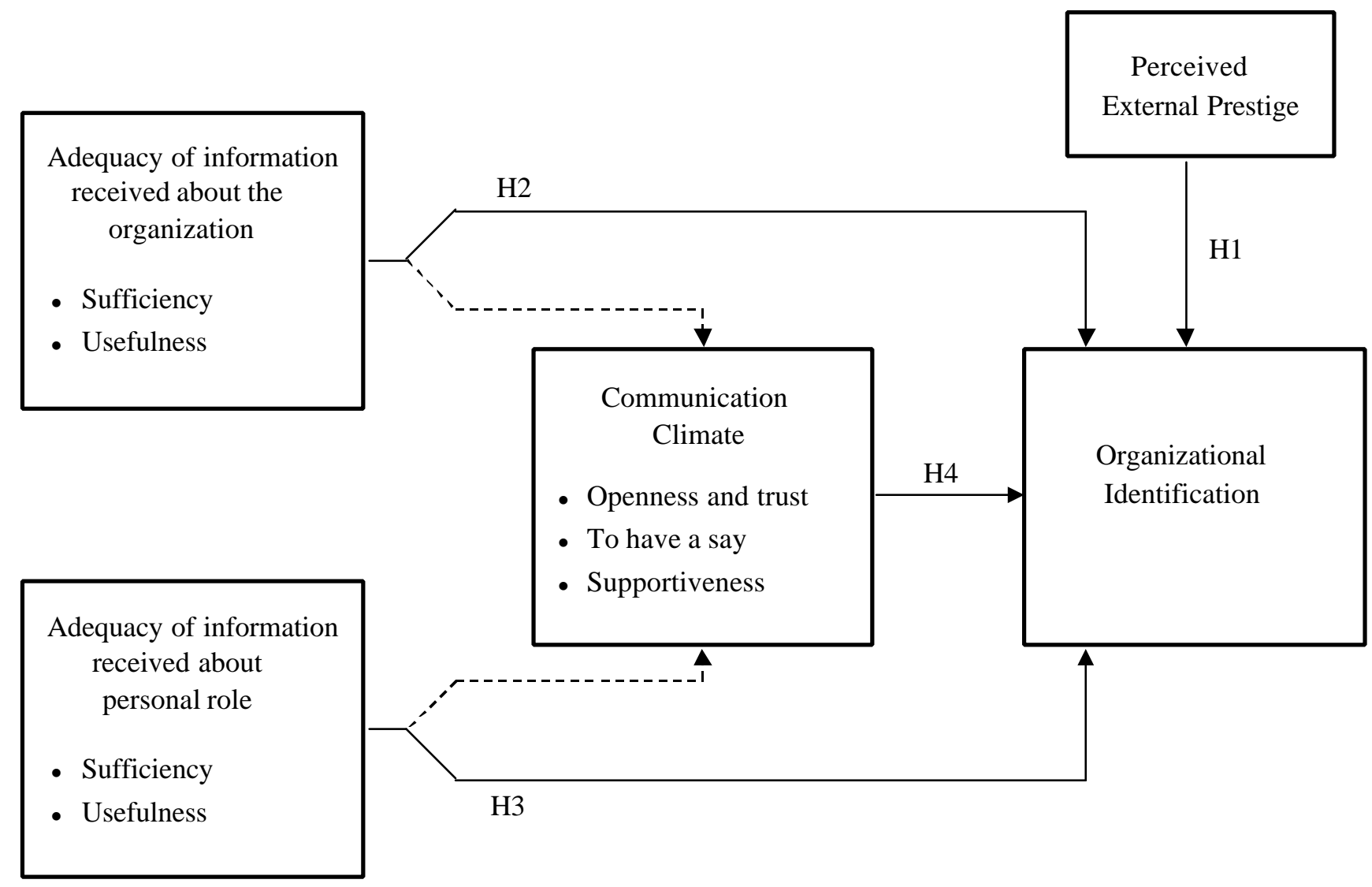

Conceptual Model of the Impact of Employee Communication and Perceived External Prestige on Organizational Identification 


\section{FIGURE 2}

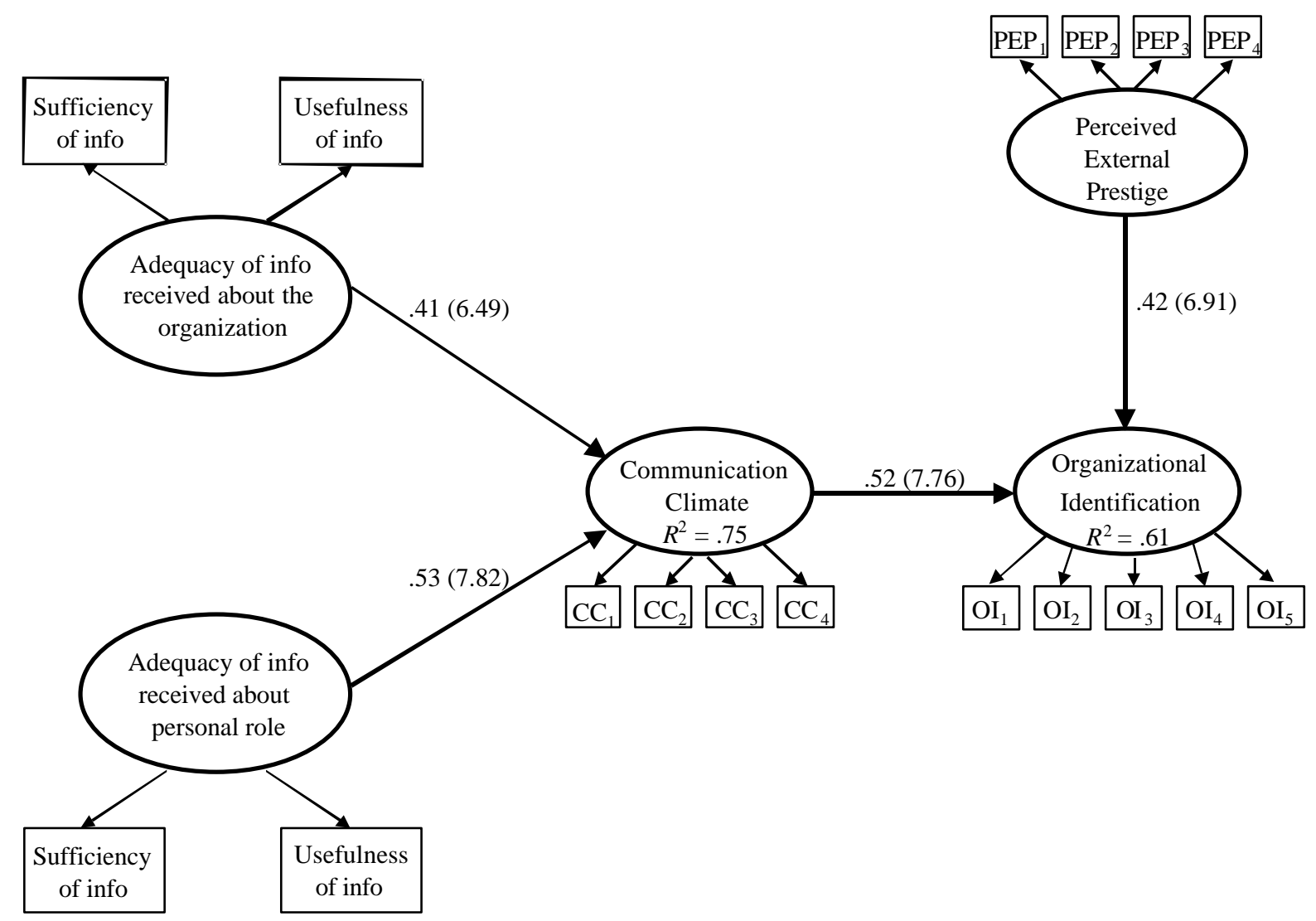

Estimated Impact of Employee Communication and Perceived External Prestige on Organizational Identification

(standardized regression coefficients, $t$-values in brackets) 
REPORT SERIES

RESEARCH IN MANAGEMENT

\begin{tabular}{|c|c|c|}
\hline \multicolumn{3}{|c|}{ BIBLIOGRAPHIC DATA AND CLASSIFICATIONS } \\
\hline Abstract & \multicolumn{2}{|c|}{$\begin{array}{l}\text { Employees' Organizational Identification (OI) is measured in a customer service } \\
\text { organization. Particularly the effects of employee communication and perceived } \\
\text { external prestige (PEP) on Ol were evaluated. Results show that employee } \\
\text { communication affects OI more strongly than PEP. One aspect of employee } \\
\text { communication, the communication climate, appears to play a central role: it mediates } \\
\text { the impact on OI of the content of employee communication. These results suggest } \\
\text { that the importance of how an organization communicates internally is even more vital } \\
\text { than the question what is being communicated. Consequences of the results for } \\
\text { managing and synchronizing internal and external communication are discussed. }\end{array}$} \\
\hline \multirow{3}{*}{$\begin{array}{l}\text { Library of Congress } \\
\text { Classification } \\
\text { (LCC) }\end{array}$} & 5001-6182 & Business \\
\hline & $5410-5417.5$ & Marketing \\
\hline & 5548.8 & Organizational Psychology \\
\hline \multirow{3}{*}{$\begin{array}{l}\text { Journal of Economic } \\
\text { Literature } \\
\text { (JEL) }\end{array}$} & M & Business Administration and Business Economics \\
\hline & M 31 & Marketing \\
\hline & L 29 & Firm Objectives, Organization \& Behavior: other \\
\hline \multirow{4}{*}{$\begin{array}{l}\text { European Business } \\
\text { Schools Library Group } \\
\text { (EBSLG) }\end{array}$} & $85 \mathrm{~A}$ & Business General \\
\hline & $280 \mathrm{G}$ & Managing the marketing function \\
\hline & $100 \mathrm{~L}$ & Organizational Behavior \\
\hline & $55 \mathrm{~B}$ & Organizational Communication \\
\hline \multicolumn{3}{|c|}{ Gemeenschappelijke Onderwerpsontsluiting (GO0) } \\
\hline \multirow[t]{3}{*}{ Classification GOO } & 85.00 & Bedrijfskunde, Organisatiekunde: algemeen \\
\hline & 85.40 & Marketing \\
\hline & 85.08 & Organisatiesociologie, Organisatiepsychologie \\
\hline \multirow[t]{3}{*}{ Keywords GOO } & \multicolumn{2}{|c|}{ Bedrijfskunde / Bedrijfseconomie } \\
\hline & \multicolumn{2}{|l|}{ Marketing } \\
\hline & \multicolumn{2}{|c|}{ Organisatiecultuur /Communicatie / Interne organisatie } \\
\hline Free keywords & \multicolumn{2}{|c|}{$\begin{array}{l}\text { Social identity theory, member identification, employee communication, } \\
\text { participation in decision making, perceived external prestige }\end{array}$} \\
\hline Other information & & \\
\hline
\end{tabular}

